\title{
Oral administration of triethylenetetramine (TETA) reduces some inflammatory markers in streptozotocin-induced diabetes mellitus in rat
}

\author{
Kaveh Azimzadeh $^{1 *}$, Hossein Jafarpour ${ }^{2}$, Farid Digaleh ${ }^{2}$, Armin Gargarechi $^{2}$
}

1. Young Researcher and Elite Club, Urmia Branch, Islamic Azad University, Urmia, Iran

2. Department of Veterinary Medicine, Veterinary faculty, Urmia Branch, Islamic Azad University, Urmia, Iran

*Corresponding author:Tel: +98 9143409583 Fax: +98 4433386733

Address: Young Researcher and Elite Club, Urmia Branch, Islamic Azad University, Urmia, Iran E-mail: kaclinpath@gmail.com

Received; 2017/11/1 revised; 2017/12/9 accepted; 2018/05/15

\begin{abstract}
Introduction: Owing to harmful effects of inflammatory markers on occurrence and progression of diabetic complications, hence, studying the possible effect of chemical components on these markers seems to be effective in diabetes mellitus. This study aimed to assess whether the triethylenetetramine (TETA), as a copper chelator, affects the plasma level of inflammatory markers such as visfatin (Vis), cholinesterase (CholE), total sialic acid (TSA) and hepcidin (Hep) in streptozotocin- induced diabetes mellitus rat.

Materials and methods: Thirty male Wistar rats were assigned for this study. After induction of diabetes mellitus, TETA with different doses $(10,20$ and $40 \mathrm{mg} / \mathrm{kg} / \mathrm{day})$ was orally administrated for 6 months. Thereupon, the above inflammatory factors were measured in all treatment groups.

Results: Plasma concentrations of Vis, CholE, TSA, Hep and glucose decreased significantly $(\mathrm{P}<0.01)$ in the highest dose group $(40 \mathrm{mg} / \mathrm{kg} /$ day $)$ compared with control group. Interestingly, by enhancement of TETA dose, these levels were lowered.

Conclusion: The results suggested that TETA administration in the dose of $40 \mathrm{mg} / \mathrm{kg} / \mathrm{day}$ leads to profound reduction of the inflammatory markers Vis, CholE, TSA and Hep, therefore may have beneficial effect on diabetes mellitus.
\end{abstract}

Keywords: Triethylenetetramine, Diabetes mellitus, Novel inflammatory markers

\section{Introduction}

Diabetes mellitus (DM) is considered as one of metabolic diseases which is mainly clarified with resistance to insulin, insulin deficiency and/or both items (1). DM involves the significant manifestations not only for premature atherosclerosis and renal disease but also for their rapid progression. Indeed, those complications are known as major cause of death in DM, wherein chronic cardiovascular and renal complications and hyperglycemia are main adjectives (2).

Copper $\left(\mathrm{Cu}^{2+}\right)$ as unbounded form, strongly possesses pro-oxidant feature in mammalian tissues and may trigger pathways that activates excessive generation of reactive oxygen species (ROS), such as the superoxide anion or hydroxyl radical and their levels may elevate under pathological conditions and cause tissue damage (3). Increased Serum $\mathrm{Cu}$ concentration is well linked with hypercholesterolemia, Macroangiopathy, hypertension and microangiopathy, in diabetic subjects (4).

TETA (trientine) belongs to structure analog of linear polyamine compounds (spermidine and spermine) and is characterized as a highly selective $\mathrm{Cu}^{2+}$ chelator wherein generally used for the treatment of Wilson's disease and recently is utilized in the diabetic ones (rat and 
human) for treatment of cardiac failure (5). $\mathrm{DM}$ is associated with a series of metabolic alterations in which $\mathrm{Cu}^{2+}$ accumulation and tissue imbalance of $\mathrm{Cu}^{2+}$ are occurred in the extracellular matrix. TETA usage boosts urinary $\mathrm{Cu}^{2+}$ excretion in patients with type $2 \mathrm{DM}$ and streptozotocin-induced diabetes mellitus type $I$ in rat. In addition, left ventricular hypertrophy along with cardiac dysfunction is ameliorated by TETA during DM. Hence, TETA can be pointed out as therapeutic agent in the attenuation of diabetes mellitus-mediated cardiovascular complications (5). Thus, beneficial effects of TETA in the experimental treatment of cardiovascular and renal disease has been determined in DM.

Visfatin with molecular weight of $52 \mathrm{KD}$, is categorized as adipocytokines (6) which is mainly secreted from visceral adipose tissue, as well as it is produced in muscles and hepatocytes. Recent studies have denoted implications of visfatin in occurrence of inflammation and stimulation of other inflammatory markers synthesis (7). Concurrent increase of serum visfatin level with some inflammatory cytokines e.g IL-6 and TNFalpha have been documented in severel studies $(8,9)$.

Cholinesterases (CholE) are included into two major enzymes (acetylcholinesterase, AchE; and butyrylcholinesterase, BChE). They are present in blood and other body fluids and involve in hydrolysis of acetylcholine (ACh). In addition, these two enzymes play crucial role in haematopoiesis, memory and participate in inflammation processes (10) and recently Da Silva (11) have introduced both of which as inflammatory markers.

Hepcidin (Hep) is categorized as small peptide with 25 amino acids which is known as inflammatory marker (12). This peptide plays fundamental role in the neutralizing of ferroportin function on the surface of macrophages, hepatocytes and expressed enterocytes and thereby increases the intracellular iron stores, reduction of iron absorption from food and circulating blood. In addition, hepcidin by stimulating the inflammatory response and reduction of iron bioavailability for bacteria, plays anti-bacterial role. In general, hepatic expression of hepcidin increases during iron overload and inflammatory stimuli such as IL-6, IL-1 and LPS (12).

Various studies have reported the effects of TETA on some biochemical markers in diabetes mellitus, however, regarding the effects of TETA on the inflammatory markers Vis, CholE, TSA and Hep, this study is the first ones that resolved the issue.

\section{Material and methods}

Animals: In this experimental study, thirty male Wistar rats $(235 \pm 25 \mathrm{~g}$, aged 2 months) were purchased from the animal house of veterinary faculty of Urmia university and were randomly divided into five groups (6 rats in each group) (A, B, C, $\mathrm{D}, \mathrm{E})$ in special cages under standard hygienic conditions and were allowed to use water and standard pellet ad libitum and 12:12 h light: dark at temperature 21$25^{\circ} \mathrm{C}$ with $39 \%$ humidity.

Induction of experimental diabetes mellitus: After 10 days of acclimatizing, dissolved streptozotocin in sterile distilled water was intravenously injected $(65$ $\mathrm{mg} / \mathrm{kg}$ ) intraperitoneally (i.p). Then, blood sampling was carried out (from tail vein) after two days and blood glucose above $250 \mathrm{mg} / \mathrm{dl}$ was observed in four groups (A, $\mathrm{B}, \mathrm{C}, \mathrm{D})$ of animals, thus considered as diabetics. It is worth nothing that the rats (group A, B, C, D) were fasted $12 \mathrm{~h}$ before and after streptozotocin injection. Also blood glucose was daily measured using glucometer GX (Ames, USA).

Experimental design and animal grouping: Animal grouping was as follows: Negative control (E) $(n=6)$; this group received distilled water without TETA. Positive control (D) $(n=6)$ : this 
group was diabetic ones that received distilled water without TETA administration. Treatment groups (A, B and $\mathrm{C}$ ); these groups (each also includes 6 rats) received different doses of TETA (10, 20 and $40 \mathrm{mg} / \mathrm{kg} / \mathrm{day}$, respectively) in distilled water via gastric gavage per day. After 6 months of TETA administration, all groups were anaesthetized with thiopental sodium (Sigma-Aldrich, USA) $(50 \mathrm{mg} / \mathrm{kg}$, i.p) and blood samples were taken via cardiac puncture and transferred to heparinized tubes and centrifuged at $6000 \mathrm{RPM}$ for 10 minutes at $4^{\circ} \mathrm{C}$, to prepare plasma.

Measurement of Plasma parameters: Prepared plasms were kept in $-20^{\circ} \mathrm{C}$ until biochemical analysis. TSA determination was carried out according to the method reported previously by Sydow et al. (13). Briefly, $400 \mu \mathrm{l}$ of plasm were mixed with $3 \mathrm{ml}$ of $5 \%$ perchloric acid for $5 \mathrm{~min}$ at $100^{\circ} \mathrm{C}$ and centrifuged at $1400 \mathrm{~g}$ for $4 \mathrm{~min}$, $2 \mathrm{ml}$ of supernatant were also mixed with $400 \mu \mathrm{l}$ of Echrlich reagent (pdimethylaminobenzaldehyde). Following incubation at $100^{\circ} \mathrm{C}$ for $15 \mathrm{~min}, 2 \mathrm{ml}$ of distilled water was added on samples and the optical density of samples at $525 \mathrm{~nm}$ was read using a spectrophotometer (UV/Visible, Cecil, Italy). CholE, glucose, total hemoglobin $(\mathrm{Hb})$ and $\mathrm{HbA} 1 \mathrm{c}$ were measured by colorimetric methods (Parsazmoon Kits, Tehran, Iran).

Commercial ELISA Kits were used for the measurement of Hep and Vis (Bioassay Technology Laboratory Co, China), NF- $\alpha$ and IL-6 (Bender MedSystems GmbH, Vienna, Austria), IL-8(Mybiosource, SanDiego, USA) and insulin Crystal chem Co, Downers Grove, USA).

\section{Statistical analysis}

The data were denoted as Mean \pm SEM. The statistical analyses were performed by one-way ANOVA and Tukey multiple comparison tests. The statistical software SPSS 17 was applied for statistical analysis and significant level was set at $\mathrm{P}$ $<0.01$.

\section{Results}

Table 1 denotes alterations of Vis, CholE, TSA, Hep and glucose in all groups. Remarkable increase of all inflammatory markers and glucose were observed in diabetic group (group D). In contrary, significant decrease of plasma Vis, CholE, TSA, Hep and glucose concentrations were observed in group $\mathrm{C}(40 \mathrm{mg} / \mathrm{kg} /$ day $)$ compared with group D (positive control). In addition, no significant changes were observed in the inflammatory markers for the groups a $(10 \mathrm{mg} / \mathrm{kg} /$ day $)$ and B $(20 \mathrm{mg} / \mathrm{kg} / \mathrm{day})$ in comparison with group D. Similar status was observed for glucose in the groups of A $(10 \mathrm{mg} / \mathrm{kg} /$ day $)$ and B $(20 \mathrm{mg} / \mathrm{kg} / \mathrm{day})$ in comparison with group E (negative control). Furthermore, $40 \mathrm{mg}$ of TETA tremendously decreased the markers and glucose in diabetic rats.

Table 2 shows significant increases of inflammatory interleukins (IL-6, IL-8, and TNF-alpha) in diabetic group. Decreased total $\mathrm{Hb}$ was observed in diabetic group after administration of TETA, especially in dose $40 \mathrm{mg} / \mathrm{kg} /$ day. Furthermore, decrease of body weight was occurred in diabetic group, but during TETA administration, the body weight was increased. Discussion In the present study, considerable decrease was occurred in all inflammatory markers and glucose during administration of TETA with dose of $40 \mathrm{mg} / \mathrm{kg} /$ day. Inflammation is considered to play essential role in the progression and complications of DM (14), and according to Pickup study (15), interleukin-induced inflammatory response is associated with pathogenesis of DM. Cytokines have been known as promotors of $\beta$-cell damage through generation of nitric oxide. IL-6 and TNF- $\alpha$ are considered as adipocytesecreted inflammatory mediators (16). The pro-inflammatory cytokines, IL-6, and TNF- $\alpha$, hinders insulin synthesis and secretion via destruction of pancreatic islets (17). In metabolic disorders such as insulin resistance, disturbances of TNF- $\alpha$ metabolism have been reported which 
Table 1. Effect of the different doses of triethylenetetramine (TETA) on the studied inflammatory in control (D and $\mathrm{E})$ and diabetic $(\mathrm{A}, \mathrm{B}, \mathrm{C})$ groups of rats.

\begin{tabular}{|c|c|c|c|c|c|}
\hline \multirow[b]{2}{*}{ Variable } & \multicolumn{2}{|c|}{ Control groups } & \multicolumn{3}{|c|}{ Diabetic groups received different doses of TETA } \\
\hline & E(Negative) & $\mathrm{D}$ (Positive) & $\mathrm{A}(10 \mathrm{mg} / \mathrm{kg})$ & $\mathrm{B}(20 \mathrm{mg} / \mathrm{kg})$ & $\mathrm{C}(40 \mathrm{mg} / \mathrm{kg})$ \\
\hline Visfatin (ng/L) & $106.52 \pm 2.16^{\mathrm{a}}$ & $191.71 \pm 3.87^{b}$ & $186.22 \pm 2.81^{\mathrm{b}}$ & $155.62 \pm 3.07^{\mathrm{c}}$ & $115.28 \pm 1.99^{\mathrm{d}}$ \\
\hline TSA (mg/dl) & $12.61 \pm 0.58^{\mathrm{a}}$ & $82.49 \pm 1.21^{\mathrm{b}}$ & $74.81 \pm 1.25^{\mathrm{c}}$ & $61.55 \pm 1.30^{\mathrm{c}}$ & $15.43 \pm 0.39^{\mathrm{d}}$ \\
\hline Hep (pg/ml) & $92.59 \pm 1.93^{\mathrm{a}}$ & $341.28 \pm 5.76^{\mathrm{b}}$ & $329.81 \pm 4.51^{\mathrm{b}}$ & $238.69 \pm 3.51^{\mathrm{c}}$ & $116.19 \pm 2.62^{\mathrm{d}}$ \\
\hline CholE (IU/L) & $856.27 \pm 16.44^{\mathrm{a}}$ & $2893.45 \pm 48.14^{b}$ & $2786.21 \pm 32.99^{b}$ & $2146.58 \pm 29.59^{c}$ & $911.53 \pm 21.54^{\mathrm{d}}$ \\
\hline Glucose (mg/dl) & $135.81 \pm 3.22^{\mathrm{a}}$ & $326.81 \pm 4.12^{\mathrm{b}}$ & $218.77 \pm 3.57^{\mathrm{c}}$ & $168.81 \pm 2.96^{\mathrm{d}}$ & $127.63 \pm 1.57^{\mathrm{e}}$ \\
\hline Insulin (ng/ml) & $47.23 \pm 0.87^{\mathrm{a}}$ & $5.879 \pm 0.152^{b}$ & $15.14 \pm 0.79^{c}$ & $23.64 \pm 0.26^{\mathrm{d}}$ & $43.29 \pm 0.81^{\mathrm{e}}$ \\
\hline
\end{tabular}

Data are expressed as mean \pm standard error. Different letters as superscript (a, b, c and d) in the row denote significant difference among groups $(\mathrm{P}<0.01)$. TSA, total sialic acid; Hep, hepcidin; CholE, cholinesterase.

Table 2. Effect of the different doses of triethylenetetramine (TETA) on TNF- $\alpha$, IL- 6 and IL- 8 in control and diabetic groups of rats.

\begin{tabular}{|c|c|c|c|c|c|}
\hline \multirow[b]{2}{*}{ Variable } & \multicolumn{2}{|c|}{ Control groups } & \multicolumn{3}{|c|}{ Diabetic groups received different doses of TETA } \\
\hline & E(Negative) & $\mathrm{D}$ (Positive) & Variable & $\mathrm{E}($ Negative) & $\mathrm{D}$ (Positive) \\
\hline TNF- $\alpha(\mathrm{pg} / \mathrm{ml})$ & $9.52 \pm 0.63^{\mathrm{a}}$ & $42.85 \pm 3.74^{b}$ & $31.11 \pm 2.23^{c}$ & $19.94 \pm 3.58^{\mathrm{d}}$ & $11.36 \pm 1.62^{\mathrm{e}}$ \\
\hline IL-6 (pg/ml) & $15.31 \pm 0.53^{\mathrm{a}}$ & $64.29 \pm 4.81^{\mathrm{b}}$ & $53.22 \pm 3.61^{\mathrm{c}}$ & $39.14 \pm 1.67^{\mathrm{d}}$ & $20.59 \pm 2.13^{\mathrm{e}}$ \\
\hline IL-8 (pg/ml) & $18.56 \pm 1.94^{\mathrm{a}}$ & $58.75 \pm 2.50^{\mathrm{b}}$ & $49.22 \pm 2.59^{c}$ & $28.81 \pm 1.08^{\mathrm{d}}$ & $21.23 \pm 1.46^{\mathrm{e}}$ \\
\hline Total $\mathrm{Hb}(\mathrm{mg} / \mathrm{dl})$ & $13.96 \pm 1.86^{\mathrm{a}}$ & $9.57 \pm 1.29^{b}$ & $10.72 \pm 2.51^{\mathrm{b}}$ & $11.22 \pm 1.94^{\mathrm{c}}$ & $12.68 \pm 1.67^{\mathrm{d}}$ \\
\hline $\mathrm{HbA}_{1 \mathrm{c}}(\%)$ & $4.26 \pm 0.73^{\mathrm{a}}$ & $13.09 \pm 2.53^{b}$ & $9.46 \pm 1.63^{\mathrm{c}}$ & $8.09 \pm 1.27^{\mathrm{c}}$ & $5.38 \pm 1.06^{\mathrm{d}}$ \\
\hline Body Weight (g) & $268.53 \pm 11.24^{\mathrm{a}}$ & $141.58 \pm 9.73^{b}$ & $187.77 \pm 12.19^{c}$ & $210.42 \pm 11.34^{\mathrm{d}}$ & $251.47 \pm 13.46^{\mathrm{e}}$ \\
\hline
\end{tabular}

Data are expressed as mean \pm standard error. Different letters as superscript (a, b, c and d) in the row denote significant difference among groups $(\mathrm{P}<0.01)$. TNF- $\alpha$, tumor necrotizing factor- $\alpha$; IL-6, interleukin-6; IL-8, interleukin-8; $\mathrm{HbA}_{1 \mathrm{c}}$, hemoglobin $\mathrm{A}_{1 \mathrm{c}}$.

Langerhans islets predominantly participate in TNF- $\alpha$ synthesis following stress and TNF- $\alpha$ possesses important role in $\beta$-cell destruction in DM (19). Netea et al (20) revealed no considerable changes in TNF- $\alpha$ concentrations in early stage of DM. In contrast, Erbagci et al (17) demonstrated increased levels of TNF- $\alpha$ in the early stage of DM which is in accordance with our study in diabetic group.

CholE is reputed to be as an inflammatory marker and its high activity has been identified in different diseases. Wolkmer (21) reported alterations in CholE activity in trypanosomiasis and Staphylococcus aureus infection and ascribed to clinical signs and immune response. In addition, direct relevance between cholinesterases (AChE and BChE) activity and inflammatory markers such as IL-6 has been documented, thereby forenamed result assert the concept that CholE activity boosts the systemic inflammatory response. In present study, serum cholinesterase level was found to be high in diabetic group than control ones. Godfrey (22) reported high amount of AchE in Langerhans islets in rat pancreas during induction of diabetes mellitus and control group and Abbott (23) determined high activity of serum BChE in type 1 and 2 DM patients. Lunkes (24) demonstrated high level of CholE in type $2 \mathrm{DM}$ which is in accordance with present study. CholE is identified as an inflammatory marker and its enhancement may reflect elevated inflammatory responses during diabetes mellitus. In diabetic group with 40 $\mathrm{mg} / \mathrm{kg} /$ day of TETA, CholE level was found to be low and there were not significant changes in the 10 and 20 
$\mathrm{mg} / \mathrm{kg} /$ day of TETA. Lu (25) reported role of TETA in reduction of some interleukins such as IL-1, IL-6, IL-8 and TNF-alpha wherein copper $\left(\mathrm{Cu}^{2+}\right)$ is known as one of the key drivers in the synthesis of inflammatory markers and due to role of TETA administration in $\mathrm{Cu}^{2+}$ chelation, inflammatory interleukins biosynthesis is lowered and owing to possible effects of IL-1, IL-6, IL-8 and TNF-alpha on CholE synthesis in liver, it may lead to reduction of CholE synthesis in the liver and resulting to low level of CholE in blood.

In respect of Hep, study of Nemeth (26) demonstrated that during chronic inflammatory conditions, the considerable synthesis of interleukins (particularly IL-6) was occurred by $\mathrm{T}$ - lymphocytes and macrophages and it play a main role in the hepcidin synthesis in liver, because, IL-6 directly stimulates hepatocytes for Hep production. Plasma Hep was high in diabetic group than negative control ones. Hep is categorized as novel inflammatory marker. There are few studies in respect of Hep levels in patients with diabetes mellitus. For example, Jiang (27) demonstrated high concentration of serum Hep in patients with DM type 2 and attributed to increased level of IL-6 which induces Hep biosynthesis in liver. It should be noted that according to recent studies, along with liver which has been known as the essential site of Hep expression and synthesis also pancreatic islets involve as additional source of Hep (28). Since, IL-6 is known as main stimulator of Hep synthesis in the liver and also various studies have reported increased levels of inflammatory interleukins, particularly IL6 following DM, hence, with most probable, high level of IL-6 occur in this study and leads to excessive synthesis of Hep. In respect of Hep decrease after oral administration of TETA (40 mg/kg/day), Ugarte (2) demonstrated attenuating effect of TETA on IL-6 levels in STZ-induced $\mathrm{DM}$ in rat and the same result was obtained by Lu study (25) about TETA effect in IL-6 decrease. In general, in present study, low level of Hep after TETA administration, particularly 40 $\mathrm{mg} / \mathrm{kg} / \mathrm{day}$, can be attributed to TETA role in lowering of IL-6.

Present study was carried out to investigate the role of TETA on some novel inflammatory markers e.g. visfatin in DM. High visfatin level was determined in diabetic group (D) compared to negative control (E). This one is in accordance with Sandeep (29)

The inflammation is well-known to play substantial role in DM occurrence as insulin resistance. In addition, proinflammatory effect and positive correlation of visfatin with inflammatory markers, such as IL-6 and CRP have been suggested $(30,31)$. In this study, visfatin elevation in diabetic group may attribute to two possible factors such as beta-cells destruction (32) and releasing from visceral adipose tissue.

TETA reduced visfatin concentration in dose of $40 \mathrm{mg} / \mathrm{kg} /$ day in diabetic group rather than negative control ones. The lowering effect of TETA on visfatin can be attributed to TETA role in reduction of IL6, because Ugarte (2) expressed impression of TETA in attenuation of IL-6 in diabetic rats. Hence, most probable, TETA with same mechanism involves in visfatin decrease in $40 \mathrm{mg} / \mathrm{kg} /$ day group.

Serum total sialic acid is known as a risk factor of cardiovascular diseases (33). Previous studies have indicated that serum TSA concentrations are elevated in diabetes mellitus (both type 1 and type2) with and without vascular complications and differences between genders (34). It is worth mentioning that a relationship between enhanced TSA with the occurrence of vascular complications is inevitable. Ekin (1) demonstrated the higher level of TSA in diabetic patients than normal subjects and implied the following plausible mechanisms for TSA increase.1) The missing of sialic acidcontaining glycoproteins from vascular cells into the bloodstream 2) cytokineevoked acute phase response (the 
production of acute phase proteins with considerable sialic acid content in liver is stimulated by cytokines) may cause to the increased serum sialic acid levels. In present study significant decrease in the TSA level was revealed in groups of A, B and especially $\mathrm{C}$ compared with group $\mathrm{E}$ (negative control) and considerable difference was observed between $\mathrm{C}$ with $\mathrm{D}$ (positive control) and E. We could not find information regarding TETAmediated sialic acid decrease. However, Rahman (35) suggested the ameliorative effect of metformin in fall of sialic acid concentration than rosiglitazone in patients with diabetes mellitus type 2 . Since, sialyl transferase involves in different metabolic pathways for adding sialic acid to glycoproteins (like some acute phase proteins) and glycolipids (LDL) (32). Thereby, it is likely that lower TSA may attribute to TETA effects on over expression and/or over-activity of sialyl transferase, consequently high demand of sialic acid and its transferring to glycoproteins and glycolipids during diabetes mellitus. It is worth mentioning that it should consider the effects of unknown mechanisms in this subject.

In respect of glucose level, TETA in dose of $40 \mathrm{mg} / \mathrm{kg} /$ day induced lowering of blood glucose. Since, restoration effect of TETA

\section{References}

1. Ekin S, Mert N, Gunduz H, Meral I. Serum sialic acid levels and selected mineral status in patients with type 2 diabetes mellitus. Biol Trace Elem Res. 2003; 94(3):193-201. doi: 10.1385/BTER:94:3:193

2. Ugarte M, Brown M, Hollywood KA, Cooper GJ, Bishop PN, Dunn WD. Metabolomic analysis of rat serum in streptozotocin-induced diabetes and after treatment with oral triethylenetetramine (TETA). Genome Med. 2012;4(4):35. doi: $10.1186 / g m 334$

3. Gong $\mathrm{D}, \mathrm{Lu} \mathrm{J}$, Chen $\mathrm{X}$, Reddy $\mathrm{S}$, Crossman DJ, Glyn-Jones S, et al. A on DM involved tissues (kidney, aorta and pancreas) has been reported previously in rabbit (35), hence, it is possible same conditions be occurred in present study and possible TETA-mediated pancreas restoration be decreased blood glucose level.

\section{Conclusion}

In conclusion, since alleviating effects of TETA on IL-1, IL-6, IL-8 and TNF-alpha (especially IL-6) in diabetic subjects has been previously reported (19) the reducing effect of TETA on CholE, Hep and TSA concentrations, as novel inflammatory markers, in diabetic rats reveal fundamental role of TETA in attenuation of DM-evoked inflammatory markers. It is worth mentioning that, owing to effective role of TETA in dose of $40 \mathrm{mg} / \mathrm{kg} /$ day (subgroup C) on decrease of those ones, forenamed dose may assign as supplementary dose along with other drugs in the diabetic patients.

\section{Acknowledgement}

The authors would like to acknowledge Dr. Kamali for helping and supporting in measurement of parameters especially, CholE and Hep.

copper (II)-selective chelator
ameliorates diabetes-evoked renal
fibrosis and albuminuria, and
suppresses pathogenic TGF-beta
activation in the kidneys of rats used as
a model of diabetes. Diabetologia.
$2008 ; 51(9): 1741-51$.
$10.1007 / \mathrm{s} 00125-008-1088-7$.

4. Walter JY, Uriu-Hare KL, Olin KL, Oster MH, Anawalt $\mathrm{BD}$, Critchfield JW, et al. Zinc, manganese and magnesium status and complications of diabetes mellitus. Diabetes Care. 1991;14(11):1050-6.

5. Lu J, Gong D, Choong SY, Xu H, Chan YK, Chen X, et al. Copper(II)-selective 
chelation improves function and antioxidant defenses in cardiovascular tissues of rats as a model of diabetes: comparisons between triethylenetetramine and three less copper-selective transition-metaltargeted treatments. Diabetologia. 2010; 53(6):1217-26. doi: 10.1007/s00125010-1698-8

6. Fukuhara A, Matsuda M, Nishizawa M, Segawa K, Tanaka M, Kishimoto K, et al. Visfatin: a protein secreted by visceral fat that mimics the effects of insulin. Science. 2005;307(5708):42630. $010.1126 /$ science. 1097243

7. Fantuzzi G, Mazzone T. Adipose tissue and atherosclerosis: exploring the connection. Arterioscler Thromb Vasc Biol. 2007;27(5):996-1003. doi:10.1161/ATVBAHA.106.131755

8. Brentano F, Schorr O, Ospelt C, Stanczyk J, Gay RE, Gay S, et al. Pre-B cell colony-enhancing factor/visfatin, a new marker of inflammation in rheumatoid arthritis with proinflammatory and matrix-degrading activities. Arthritis Rheum. 2007; 56(9):2829-39. doi:10.1002/art.22833

9. Chen MP, Chung FM, Chang DM, Tsai JC, Huang HF, Shin SJ, et al. Elevated plasma level of visfatin/pre-B cell colony enhancing factor in patients with type 2 diabetes mellitus. J Clin Endocrinol Metab. 2006;91(1):295-9. doi:10.1210/jc.2005-1475

10. Kimura R, Ushiyama N, Fuji T, Kawashima K. Nicotine induced $\mathrm{Ca} 2+$ signaling and down-regulation of nicotinic acetylcholine receptor subunit expression in the CEM human leukemic T-cell line. Life Sci. 2003; 72(1819):2155-8. doi.org/10.1016/S00243205(03)00077-8

11. Da Silva CB, Wolkmer P, Da Silva AS, Paim FC, Tonin AA, Castro VSP, et al. Cholinesterases as markers of the inflammatory process in rats infected with Leptospira interrogans serovar Icterohaemorrhagiae. J Med Microbiol.
2012; 61(Pt 2):278-84. doi: 10.1099/jmm.0.035501-0.

12. Park $\mathrm{CH}$, Valore EV, Waring AJ, Ganz T. Hepcidin, a urinary antimicrobial peptide synthesized in the liver. J Biol Chem. 2001; 276(11):7806-10. doi:10.1074/jbc.M008922200

13. Sydow G. A simpllifield quick method for determination of sialic acid in serum. Biomedica Biochimica Acta. 1985; 44(11-12): 1721-23.

14. Dandona P, Aljada A, Bandyopadhyay A. Inflammation: the link between insulin resistance, obesity and diabetes. Trends Immunol. 2004; 25(1):4-7.

15. JC. Inflammation and activated innate immunity in the pathogenesis of type 2 resistance, obesity and diabetes. Diabetes Care. 2004; 27(3):813-23. doi: 10.1016/j.it.2003.10.013

16. Peraldi P, Spiegelman B. TNF-alpha and insulin resistance: summary and future prospects. Mol and Cell Biochem. 1998; 182(1-2):169-175. doi.org/10.1023/A:1006865715292.

17. Erbagci AB, Tarakcioglu M, Coskun Y, Sivasli E, Sibel Namiduru E. Mediators of inflammation in children with type I diabetes mellitus: cytokines in type I diabetic children. Clin Biochem. 2001; 34(8):645-650. doi: 10.1016/S00099120(01)00275-2

18. Groop LC, Saloranta C, Shank M, Bonadonna RC, Ferrannini E, DeFronzo RA. The role of free fatty acid metabolism in the pathogenesis of insulin resistance in obesity and noninsulin dependent diabetes mellitus. J Clin Endocrinol Metab. 1991; 72(1):96107. doi:10.1210/jcem-72-1-96

19. DoganY, Akarsu S, Ustundag B,Yilmaz E, Gurgoz MK. Serum IL-1beta, IL-2, and IL-6 in insulin-dependent diabetic children. Mediators Inflamm. 2006; 2006(1):59206. doi: 10.1155/MI/2006/59206.

20. Netea MG, Hancu N, Blok WL, Grigorescu-Sido P, Popa L, Popa V, et al. Interleukin 1 beta, tumour necrosis factor-alpha and interleukin 1 receptor 
antagonist in newly diagnosed insulindependent diabetes mellitus: Comparison to long-standing diabetes and healthy individuals. Cytokine. 1997; 9(4):284-7. doi:10.1006/cyto.1996.0165

21. Wolkmer P, Lopes STA, Franciscato C, da Silva AS, Traesel, CK, Siqueira et al. Trypanosoma evansi: cholinesterase activity in acutely infected Wistar rats. Exp Parasitol. 2010; 125(3):251-5. doi: 10.1016/j.exppara.2010.01.024. doi.org/10.1016/j.exppara.2012.08.015

22. Godfrey DA, Matschinsky FM. Enzymes of the cholinergic system in islets of Langerhans. $\mathrm{J}$ Histochem Cytochem. 1975; 23(9):645-51. DOI:10.1177/23.9.126256

23. Abbott CA, Mackness MI, Kumar S, Olukoga AO, Gordon C, Arrol S, et al. Relationship between serum butyrylcholinesterase activity, hypertriglyceridaemia and insulin sensitivity in diabetes mellitus. Clin Sci. 1993; 85:77-81.

DOI: $10.1042 / \mathrm{cs} 0850077$

24. Lunkes G, Stefanello F, Sausen Lunkes D, Maria Morsch V, Schetinger MR, Gonçalves JF. Serum cholinesterase activity in diabetes and associated pathologies. Diabetes Res Clin Pract. 2006; 72(1):28-32. doi.org/10.1016/j.diabres.2005.08.009.

25. Lu J. Triethylenetetramine Pharmacology and Its Clinical Applications. Mol Cancer Ther. 2010; 9(9):2458-67. doi: 10.1158/15357163.MCT-10-0523.

26. Nemeth E, Rivera S, Gabayan V, Keller C, Taudorf S, Pedersen BK, et al. IL-6 mediates hypoferremia of inflammation by inducing the synthesis of the iron regulatory hormone hepcidin. J Clin Invest. $\quad 2004 ; \quad 113(9): 1271-6$. doi:10.1172/JCI20945.

27. Jiang F, Sun ZZ, Tang YT, Xu C, Jiao $X Y$. Hepcidin expression and iron parameters change in Type 2 diabetic patients. Diabetes Res Clin Pract. 2011;
93(1):43-8.

doi:

10.1016/j.diabres.2011.03.028.

28. Kulaksiz H, Fein E, Redecker $P$, Stremmel W, Adler G, et al. beta-cells express a hepcidin, iron-uptake regulatory peptide. J Endocrinol. 2008; 197(2):241-9. doi: 10.1677/JOE-070528 .

29. Sandeep S, Velmurugan K, Deepa R, Mohan V. Serum visfatin in relation to visceral fat, obesity, and type 2 diabetes mellitus in Asian Indians. Metabolism. 2007;56(4):565-70.

doi:10.1016/j.metabol.2006.12.005

30. Seo JA, Jang ES, Kim BG, Ryu OH, Kim HY, Lee KW. et al. Plasma visfatin levels are positively associated with circulating interleukin-6 in apparently healthy Korean women. Diabetes Res Clin Pract. 2007; 79(1):108-11. doi.org/10.1016/j.diabres.2007.04.016

31. Oki K, Yamane K, Kamei N, Nojima H, Kohno K. Circulating visfatin level is correlated with inflammation, but not with insulin resistance. Clin Endocrinol (Oxf). 2007; 67(5):796-800. doi: 10.1111/j.1365-2265.2007.02966.x

32. Lopez-Bermejo A, Chico-Julia B, Fernandez-Balsells M, Recasens M Esteve E, Casamitjana R, et al. Serum Visfatin Increases with Progressive Beta-Cell Deterioration. Am Diabetes Assoc. 2006; 55(10):2871-5. doi.org/10.2337/db06-0259.

33. Gopaul KP, Crook MA. Sialic acid: A novel marker of cardiovascular disease? Clin Biochem. 2006; 39(7):667-81. doi.org/10.1016/j.clinbiochem.2006.02. 010.

34. Rahman IU, Malik SA, Bashir M, Khan RU, Idrees M. Serum sialic acid changes in type 2 diabetic patients on metformin or rosiglitazone treatment. $\mathbf{J}$ Clin Pharm Ther. 2010; 35(6):685-90. doi: $10.1111 / \mathrm{j} .1365-$ 2710.2009.01145.x.

35. Golam Mohebbi R, Azimzadeh K, Amniattalab A. Triethylenetetramine reduces some blood parameters in 
alloxan-induced diabetes mellitus in New Zealand white rabbit: evidence for histopathologic effects. Pharm Biomed
Res. 2016; 2(4): 44-51. doi: 10.18869/acadpub.pbr.2.4.44. 